\title{
Methadone-related QT prolongation and arrhythmic storm in an addicted patient: What weapons to use in a lost war?
}

\author{
Angela Nicotera, Pasquale Crea, Maurizio Cusmà Piccione, Antonio Giordano, \\ Giuseppe Picciolo, Francesco Luzza
}

Department of Clinical and Experimental Medicine, University Hospital of Messina, Messina, Italy

\section{ARTICLE INFO}

Article history:

Received: 7. 3. 2016

Accepted: 14. 4. 2016

Available online: 13. 5. 2016

Klíčová slova:

Arytmická bouře

Metadon

Prodloužení intervalu QT

Užívání drog

Ztráta vědomí

\section{SOUHRN}

U pacientů léčených antidepresivy, antipsychotiky, diuretiky, antiarytmiky atd. se lze často setkat s prodloužením intervalu QT indukovaným podáním jiné látky. Po vysazení této látky dochází k obnově normálního intervalu QT. Na naše oddělení byl pro synkopu přijat 50letý muž s uživáním heroinu v anamnéze a léčený metadonem; příležitostně užíval kokain. Den před př́ijmem zvracel a měl průjem. Elektrokardiogram prokázal sinusovou bradykardii a prodloužený korigovaný interval QT. Hodnoty draslíku v séru byly poměrně nízké. Během monitorování EKG došlo opakovaně k rozvoji torsade de pointes degenerujících ve fibrilaci síní se ztrátou vědomí (řešenou aplikací stejnosměrného elektrického výboje). Komorové arytmie se podařilo zrušit infuzí isoproterenolu. Vzhledem k možnosti neúspěšné náhrady opioidu a k nedostatku informací o genetickém substrátu prodloužení intervalu QT byl muži implantován kardioverter-defibrilátor (ICD). Léčba pacientů s prodloužením intervalu QT indukovaným metadonem není snadná, hlavně kvůli obtížnému nahrazení nebo náhlému vysazení uvedené látky. $V$ akutních případech představuje infuzní aplikace isoproterenolu dobrou volbu. $V$ dlouhodobém horizontu je implantace ICD vhodným způsobem léčby zaměřené na prevenci náhlé srdeční smrti u dané populace. U pacientů léčených metadonem se osvědčuje časté monitorování EKG jako prevence prodloužení intervalu QT a rizika vzniku arytmie.

(C) 2016 Published by Elsevier Sp. z o.o. on behalf of the Czech Society of Cardiology.

\begin{abstract}
Drug-induced QT prolongation is a common finding in patients on therapy with antidepressants, antipsychotic, diuretics, antiarrhytmic drugs, etc. Drug's interruption normally restored QT interval. A 50-year-old man, with a history of abuse of heroin in treatment with methadone, was admitted in our department for syncope. He made occasional abuse of cocaine. On the day before he had vomited and diarrhea. The electrocardiogram showed sinus bradycardia and a prolonged corrected QT interval. Serum potassium levels resulted quite low. During the ECG monitoring, multiple torsade de pointes degenerating in ventricular fibrillation with loss of consciousness occurred (treated with prompt DC-shock). Infusion of isoproterenol was undertaken resulting in suppression of ventricular arrhythmias. Considering the possibility of failure of opioid's replacement and the unknown genetic substrate of the QT prolongation, ICD implantation was performed. Management of patients with methadone-related QT prolongation is not simple, mainly due to difficulty in replacing or sudden interruption of this drug. Isoproterenol infusion is a good choice in the acute setting. In the long term, ICD is probably an appropriate therapy in order to prevent sudden death in this particular population. Frequent ECG monitoring is useful to prevent QT prolongation and arrhythmic

risk in patients treated with methadone.
\end{abstract}

Keywords:

Arrhythmic storm

Drug abuse

Loss of consciousness

Methadone

QT prolongation

Address: Pasquale Crea, MD, Department of Clinical and Experimental Medicine, University Hospital of Messina, Via Consolare Valeria, 98124 Messina, Italy, e-mail: pasqualecrea@hotmail.it, pasqualecrea85@gmail.com DOI: 10.1016/j.crvasa.2016.04.004 


\section{Introduction}

Long QT syndrome (LQTS) is a group of heterogenous disorders characterized by lengthening of the cardiac repolarization caused by alterations in the transmembrane potassium, sodium and calcium currents. LQTS manifests on the electrocardiogram (ECG) as lengthening of the QT interval and it is associated with torsade de pointes $(T d P)$, ventricular tachycardia and sudden cardiac death due to ventricular fibrillation. LQTS are typically categorized as either congenital or acquired. There is subclinical or "forme fruste" of LQTS which is characterized by the presence of an altered genotype which manifests phenotypically in the presence of triggers such as drugs or other predisposing factors. The vast majority of drug-induced forms of LQTS are mediated through the block of the rapid delayed rectifier potassium current (lkr) resulting in a delay in the phase 3 of the ventricular action potential. The prolonged repolarization can trigger early after depolarizations (EADs). The EADs can generate ventricular extrasystoles that can serve to initiate TdP. Therapy with antidepressants, antipsychotic, diuretics, antiarrhytmic drugs, etc. may induce QT prolongation. Drug's interruption usually restored normal QT interval.

\section{Case report}

A 50-year-old man, HCV positive, with a history of abuse of heroin in treatment with methadone (150 mg/die), was admitted in our department for syncope. He made occasional abuse of cocaine. The day before admission he suffered of vomit and diarrhea, related to an indigestion. The electrocardiogram showed sinus bradycardia (50 bpm), with early coupled ventricular extrasystoles and a prolonged corrected QT (QTC) interval, measuring about $600 \mathrm{~ms}$ (Fig. 1). During the ECG monitoring, multiple torsade de pointes (TdP) (Fig. 2 , panel $A$ ), often degenerating in ventricular fibrillation with loss of consciousness (LoC), occurred. Episodes of ventricular fibrillation were promptly treated with DC-shock (Fig. 2, panel B). The patient refused overdrive pacing tre- atment. Infusion of isoproterenol was undertaken, resulting in a rapid increase of heart rate and suppression of ventricular arrhythmias. The ECG obtained during sinus tachycardia showed a long QT interval with a bifid morphology of the $T$ wave in the precordial leads (Fig. 3, panel A). Serum potassium levels resulted just below the normal value (3.4 $\mathrm{mmol} / \mathrm{L}$ ). Potassium and magnesium sulphate infusions were administered. Infusion of isoproterenol was interrupted two days later. Echocardiogram showed no structural heart disease. The patient underwent coronary angiography that showed absence of coronary artery disease. ECG in first-degree relatives did not show QT prolongation. Family history was negative for syncope or sudden cardiac death. Methadone is a cause of QT prolongation and Tdp [1]. Moreover cocaine blocks the delayed rectifier potassium ion channel in cardiac myocytes probably contributing in prolonging the QT interval [2]. In this particular case, methadone and cocaine acted together; vomit and diarrhea, inducing slight hypokalemia, amplified this condition leading to an arrhythmic storm. Methadone's assumption cannot be immediately interrupted and its eventual replacement with buprenorphine (another opioid with less QT interval effects) has to be gradual [3]. During 20 days of hospitalization methadone daily dose was reduced gradually down to $90 \mathrm{mg}$. Considering the unpredictable period needing to stop methadone, the possibility of failure of opioid's replacement due to poor patient compliance and the unknown genetic substrate of the QT prolongation ( $\mathrm{K}+$ channel genetic mutation and/or polymorphisms?) we decided to implant an ICD. We warned the patient of the high risk of endocarditis in case of intravenous drug abuse. ECG at discharge showed persistent long QT with flat T wave (Fig. 3, panel B). Patient was addressed to a rehabilitation center. One month later he failed to discontinue methadone and his ECG resulted unchanged.

\section{Discussion}

Although acute drugs abuse is a frequent cause of LoC and life-threatening arrhythmias in addicted patients, collateral effects of opioid replacement therapy have to

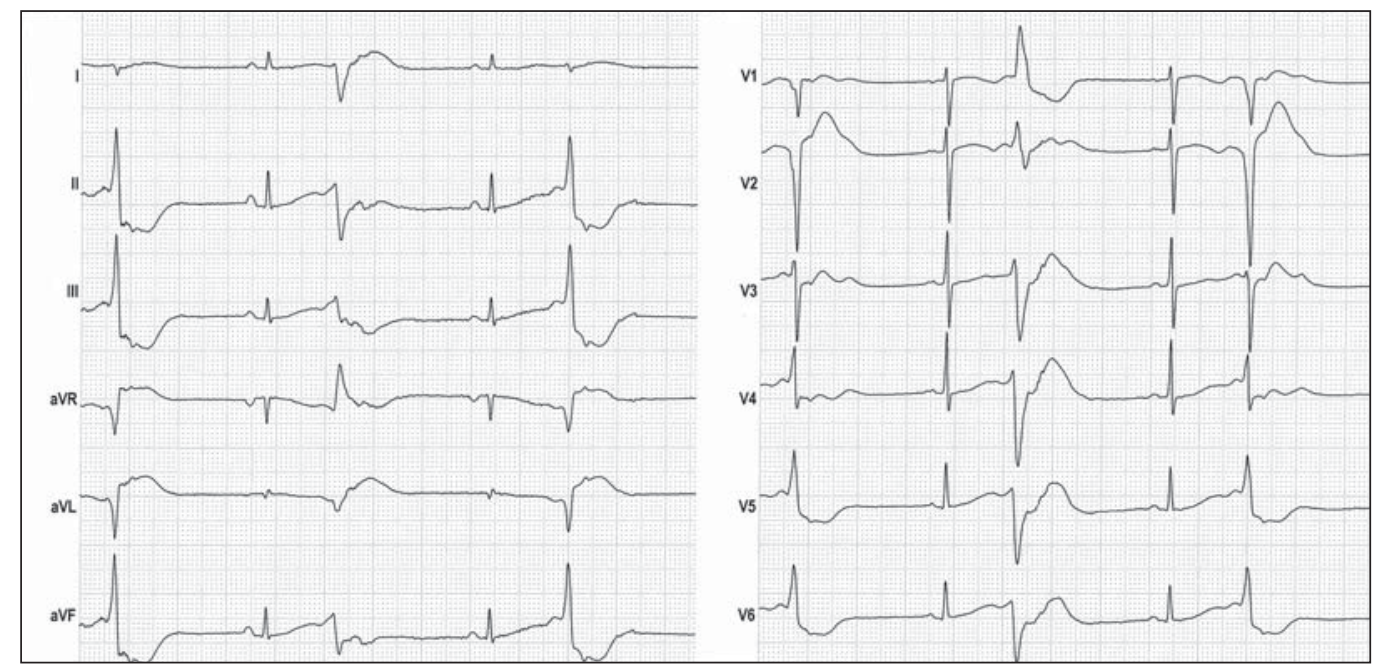

Fig. 1 - ECG in Emergency Department showing sinus bradycardia, QT prolongation and early-coupled polymorph ventricular extrasystoles. 


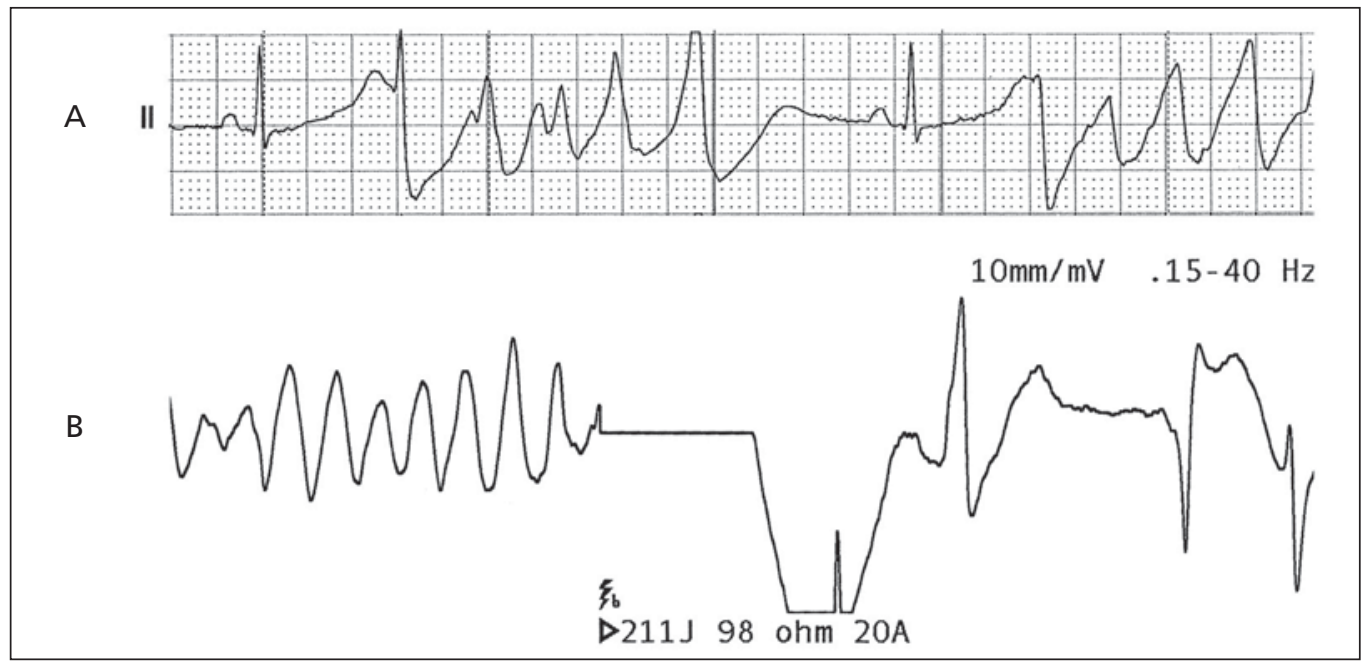

Fig. 2 - (A) Self-terminating torsade de pointes; (B) ventricular fibrillation treated with DC-shock.

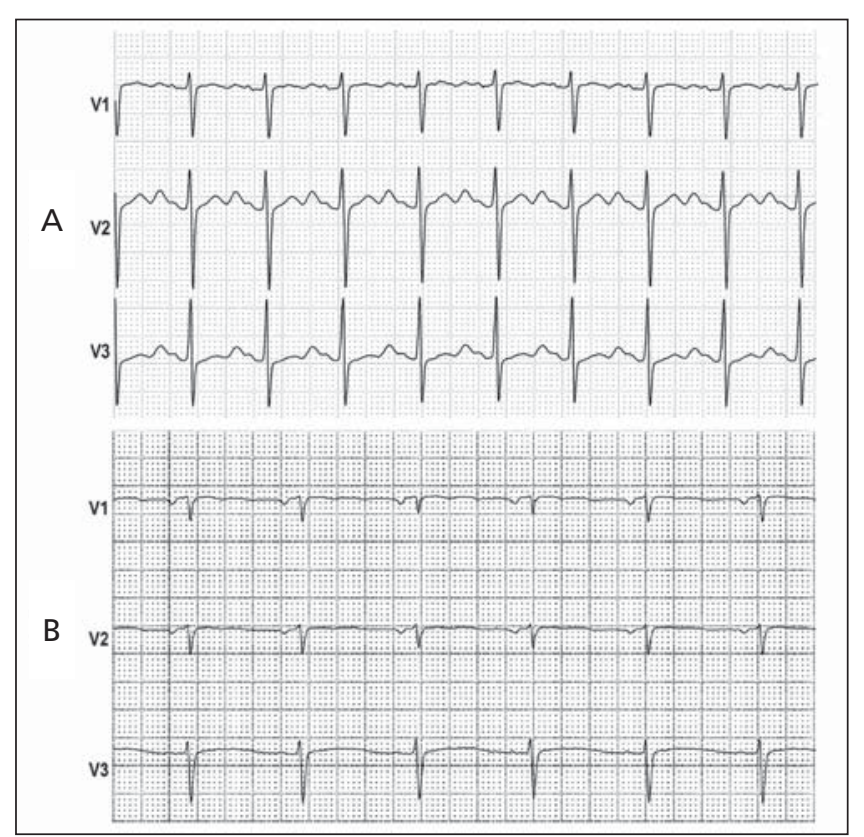

Fig. 3 - (A) ECG during isoproterenol infusion; (B) ECG at 1 discharge.

be taken into account. Clinical guidelines recommend methadone as the first line of opioid substitution therapy. Methadone has also an important role in the management of severe chronic pain, whether from cancer or other causes. While methadone has proven efficacy in reducing the use of non-prescription opioids and in alleviating pain, it has the potential for serious adverse effects and it is independently associated with a prolonged QT interval. It is known to inhibit the cardiac potassium channel encoded by the human Ether-à-go-go gene (hERG). Drug-induced blockade of the hERG in vivo manifests as a prolongation of QT interval [1]. In addition methadone can exert a calcium channel antagonist effect, resulting in bradycardia [1]. Thanks to these multiple effects of QT prolongation, methadone poses a significant risk for the development of torsedes de po- intes (TdP) and ventricular arrhythmias, especially in the presence of concomitant factors such as hypokalemia [1]. The patient herewith reported was on therapy with a high daily dose of methadone $(150 \mathrm{mg})$ but he never underwent routine ECGs. Moreover, he made occasional abuse of cocaine that is known to block the delayed rectifier potassium ion channel in cardiac myocytes, the principal mechanism for drug-induced QT prolongation. The combination of these two drugs, with transient slight hypokalemia, provoked TdP. Emergency physicians and cardiologists are not confident with methadone administration. Management of patients with methadone-related QT prolongation is not simple, mainly due to difficulty in replacing or sudden interruption of this drug. Frequent ECG monitoring is useful to recognize QT prolongation and to prevent arrhythmic risk in patients using methadone for heroin addiction or chronic pain [4]. Buprenorphine is an opioid with less QT interval effects. It represents a good alternative in patients whose ECG showed methadone-related QT prolongation and ventricular arrhythmias. However, the replacement of methadone with buprenorphine is usually not easy [3]. Therefore, these patients often continue methadone treatment and ICD implantation should be considered [5]. Recently left cardiac sympathetic denervation was proposed in order to reduce arrhythmic risk in patients who cannot discontinue methadone and at high risk of infection related to ICD implantation [6].

\section{Conclusion}

Methadone is a, probably not adequately known, cause of QT prolongation, predisposing at risk of TdP especially in the presence of concomitant factors such as hypokalemia, bradycardia. In the acute setting, especially when overdrive pacing is not available, isoproterenol infusion is a good choice to prevent TdP. In the long term the replacement of methadone with buprenorphine has to be considered, but ICD is probably the most appropriate therapy in order to prevent sudden death. 


\section{Conflict of interest}

None declared.

\section{Funding body}

None.

\section{Ethical statement}

Authors state that the research was conducted according to ethical standards.

\section{Informed consent}

The patient was asked to consider allowing Dr. Pasquale Crea to use his medical records to write a case report. The case report has been fully explained to the patient and all questions have been answered. We explained to the patient the objective of this manuscript, share information experienced by one patient during his clinical care that may be useful for other physicians and members of a health care team, and may be published in Cor et Vasa Journal for others to read.
The patient authorized access to his personal health information and he has agreed to participate in this case report.

\section{References}

[1] S. Mujtaba, J. Romero, C.C. Taub, Methadone, QTc prolongation and torsades de pointes: current concepts, management and a hidden twist in the tale?, Journal of Cardiovascular Disease Research 4 (2013) 229-235.

[2] M.J. Krantz, W.A. Baker, J. Schmittner, Cocaine and methadone: parallel effects on the QTc interval, American Journal of Cardiology 98 (2006) 1121.

[3] I.M. de Jong, G.S. de Ruiter, Buprenorphine as a safe alternative to methadone in a patient with acquired long QT syndrome: a case report, Netherlands Heart Journal 21 (2013) 249-252.

[4] S. Mayet, M. Gossop, N. Lintzeris, et al., Methadone maintenance, QTc and torsade de pointes: who needs an electrocardiogram and what is the prevalence of QTC prolongation?, Drug and Alcohol Review 30 (2011) 388-396.

[5] A.M. Patel, J.P. Singh, J.N. Ruskin, Role of implantable cardioverter-defibrillators in patients with methadone-induced long QT syndrome, American Journal of Cardiology 101 (2008) 209-211.

[6] M.A. Miller, K. Bhasin, V.Y. Reddy, A. d'Avila, Left cardiac sympathetic denervation for the treatment of methadoneinduced long QT syndrome, Heart Rhythm 8 (2011) 1955-1957. 